\title{
Antibiotic Susceptibility Assessment of Bacteria Isolated from Ready- to-Drink Herbal Medicines Marketed within Kaduna Metropolis
}

\author{
Jamilu, $H$. \\ Department of Applied Biology \\ Kaduna polytechnic \\ Kaduna, Nigeria
}

\author{
Aliyu, A. \\ Department of Applied Biology \\ Kaduna polytechnic \\ Kaduna, Nigeria
}

\author{
Gambo, J.B. \\ Department of Applied Biology \\ Kaduna polytechnic \\ Kaduna, Nigeria
}

\begin{abstract}
The study of susceptibility assessment of microbial flora from ready-to-drink herbal medicine was aimed to isolate the identify bacteria associated with ready-to-drink herbal products marketed within Kaduna metropolis. The susceptibility of the isolates to commonly-used antibiotics was also determined. The assessment of the contamination of the herbal products was carried out using standard procedures (total aerobic plate count) while the isolation, identification and antibiogram of selected bacterial pathogens was done using the Kirby-bauer method. The microbial analysis was carried out on twenty one (21) ready-to-drink herbal products with total mean bacterial count ranging from $3.5 \times 107$ to $4.14 \times 107 \mathrm{cfu} / \mathrm{ml}$. The result also revealed that the sample had 40 bacterial isolates. The herbal drinks had a total mean aerobic bacterial plate count greater than $107 \mathrm{cfu} / \mathrm{ml}$. Of all, $32.5 \%$ of the herbal products were contaminated with Escherichia coli, 17.5\% Bacillus moniliformis, Staphylococcus aureus $22.5 \%$, Pseudomonas aeruginosa $12.5 \%$ while $7.5 \%$ each was found with Klebsiella spp and Streptobacillus spp respectively. The results of antibiogram on the bacterial isolates revealed that all the bacterial isolates were more susceptible to Ciprofloxacin, Pefloxacin and Gentamycin. The ready-to-drink herbal products marketed in Kaduna metropolis are highly contaminated with potential pathogenic bacterial and its preparation needs strict hygienic practices and sanitation to reduce contamination of the product to make it safe for consumption.
\end{abstract}

Keywords: Bacteria, Susceptibility, Antibiogram, Contamination, Herbal drink, Kaduna.

\section{INTRODUCTION}

Herbal medicine, also called phytomedicine or botanical medicine, refers to the use of any plant; seed, roots leaves, banks, flowers fruits, for medicinal purposes (Hassan et al., 2009). Plants with medicinal properties, popularly referred to as gift of mother nature to mankind, are in use for centuries in the traditional systems of medicines like Ayurveda, Unami, traditional Chinese medicines in India and other countries for the treatment of diseases. They are considered to be effective and non-toxic. They have a vast potential but are partly explored by the modern methods. (Moquine et al., 2009). The history of using herbs is inextricably interwined with that of modern medicine. Many synthetic drugs listed as conventional medication were originally derived from plants, for example, the antimalarial drugs quinine from Cinchona species (Tatjanat et al., 2012).

Traditional herbalists in Nigeria use various herbal preparations to treat various types of ailments including diarrhea, urinary tract infections, typhoid fever and skin diseases (Sofowora, 1993). Most of the herbal preparations are used in different forms and may carry a large number of various kinds of microbes originating from soil, usually adhering to the leaves, stem, flowers, seeds and roots of such herbs (Adeleye et al., 2004).

The World Health Organization (WHO, 2007) survey indicated that about $70-80 \%$ of the world population, particularly in developing countries, rely on non-conventional medicines, mainly of herbal origin, for their primary health care. This is because herbal medicines are more accessible and cheaper (Sofowora, 1993). The WHO (2007) explains that quality is the basis of reproducible efficacy and safety of herbal drugs and to ensure the standard of research on herbal medicines, the quality of the plant materials or preparation is of utmost importance. Omoikhudu et al., (2011) showed that the quality criteria for herbal drugs are based on a clear scientific definition of the raw material. It is difficult to establish compressive quality criteria for herbal drugs due to "professional secrecy" of herbalists. The contaminants that present serious hazards are pathogenic bacteria; such as Salmonella specie, Escherichia coli, Staphylococcus aureus, Shigella species and other Gram-positive as well Gramnegative strains of bacteria (Okunola et al., 2007).

A greater number of residents in Kaduna metropolis depends on traditional herbalists, for their healthcare needs owing to the rising cost of orthodox medicine and emergence of drugs resistant microbial strains. This justify the decision to investigate the microbial safety of these products as consumption of contaminated ready-to-drink herbal products can lead to another infection or diseases like acute gastroenteritis, cholera, typhoid fever, Staphylococcal poisoning, shigellosis etc. This work seeks to investigate the microbiological quality of the ready-to-drink herbal products sold within Kaduna metropolis and susceptibility of the bacterial isolates to some commonly used antibiotics.

\section{MATERIAL AND METHODS}

A total of 21 samples of ready-to-drink herbal drinks were purchased from kurmin mashi, Bakin dogo and Sabon tasha in a sterile containers and transported aseptically to the Department of Applied Biology Microbiology laboratory of Kaduna Polytechnic for analysis.

\subsection{Total Aerobic Plate Count}

A stock solution of the sample was prepared by dispensing $1 \mathrm{ml}$ of the sample in $9 \mathrm{ml}$ of sterile peptone water and shaked. A $\mathrm{ml}$ of the solution was pipetted into another test tube containing $9 \mathrm{ml}$ of sterile peptone water to achieve the second fold dilution. This was continued until the desired dilution was obtained and $0.1 \mathrm{ml}$ of the seven fold dilution $\left(10^{-7}\right)$ was pipetted aseptically onto the surface of each of the two duplicate plates containing $15 \mathrm{ml}$ of solidified sterile Mac- 
conkey and nutrient agar media. It was spread evenly with a sterile glass spreader aseptically. After inoculation, the plates were incubated at $37^{\circ} \mathrm{C}$ for 24 hours. Bacterial colonies were enumerated using the counter and expressed as colony forming unit (cfu/milliliter) (Chessbrough, 2008).

The isolates from nutrient and Macconkay agar were subcultured onto another plates aseptically using the same media and pure isolates were obtained. These isolates were further subcultured into universal slant bottles containing nutrient agar for further use.

\section{ANTIBIOTICS SUSCEPTIBILITY TESTING}

Bacteria isolated from the herbal drinks were screened for their susceptibility to the selected antibiotics. This was done by inoculating pure isolate from the slant bottle onto a Mueller- Hinton agar surface and spread evenly using a sterile wire loop. A sterile pair of forceps was used to place the appropriate antibiotic test discs on the surface of the inoculated plates and incubated at $370 \mathrm{C}$ for $18 \mathrm{hr}$. The diameters of the zones of inhibition were measured (Chessbrough, 2008).The antibiotics used included: Pefloxacin, Gentamycin, Augmentin, Ofloxacin, Amoxicillin, Chloranphenicol, Ciprofloxacin, Sparfloxacin, Septrin, Strepomycin, Rocephin, Erythromycin and Zinnacef.

\section{RESULT AND DISCUSSION}

Table 1: Total Mean Bacterial count of Isolates from Ready-to-Drink Herbal products obtained from different areas within Kaduna metropolis

\begin{tabular}{llll}
\hline S/No & Kurminmashi & Bakindogo & Sabontasha \\
\hline 1. & $3.2 \times 10^{7} 4$. & $1 \times 10^{7} 3$. & $8 \times 10^{7}$ \\
2. & $4.5 \times 10^{7} 3$. & $7 \times 10^{7} 3$. & $6 \times 10^{7}$ \\
3. & $2.9 \times 10^{7} 3$. & $6 \times 10^{7} 4$. & $5 \times 10^{7}$ \\
4. & $3.9 \times 10^{7} 5$. & $2 \times 10^{7} 2$. & $9 \times 10^{7}$ \\
5. & $3.0 \times 10^{7} 4$. & $7 \times 10^{7} 4$. & $3 \times 10^{7}$ \\
6. & $2.8 \times 10^{7} 4$. & $3 \times 10^{7} 3$. & $1 \times 10^{7}$ \\
7. & $4.2 \times 10^{7} 3$. & $4 \times 10^{7} 3$. & $5 \times 10^{7}$ \\
\hline $\begin{array}{l}\text { Total } \\
\text { mean }\end{array}$ & $3.5 \times 10^{7} 4$. & $14 \times 10^{7} 3$. & $7 \times 10^{7}$ \\
count & & & \\
\hline
\end{tabular}

The result of the mean bacterial count shows that various pathogenic bacteria were found in ready-to-drink herbal products studied. Most of the medicinal plants are prepared in an open environment and in unhygienic condition, which leads to contamination of the herbal preparation by some pathogenic bacteria. In this study, the total mean aerobic bacteria counts from all the three locations ranges from $3.5 \mathrm{x}$
$10^{7} \mathrm{cfu} / \mathrm{ml}$ to $4.14 \times 10^{7} \mathrm{cfu} / \mathrm{ml}$ among the bacterial isolates from the indigenous orally consumed herbal medications. The total mean bacterial count in this present study is in agreement with work of Ogunshe and Kolajo (2006) who obtained high bacterial count on indigenous medicinal preparations. The reason for high bacterial count could be due to preparation and handling of plant products, poor environmental sanitation and storage conditions.

Table 2: Percentage occurrence of organisms Isolated from herbal products

\begin{tabular}{lllll}
\hline Organisms & $\begin{array}{l}\text { Isolate } \\
\mathbf{d}\end{array}$ & $\begin{array}{l}\text { Occurrenc } \\
\text { es }\end{array}$ & $\begin{array}{l}\text { Percentag } \\
\text { e }\end{array}$ & $\begin{array}{l}\text { Occurre } \\
\text { nce }\end{array}$ \\
& & & (\%) & \\
\hline Staphylococcus aureus & 9 & 2 & 2 & 5 \\
Escherichia coli & 1 & 3 & 2 & 5 \\
$\begin{array}{l}\text { Pseudomonas } \\
\text { aeruginosa }\end{array}$ & 5 & 1 & 2 & 5 \\
Bacillus moniformis & 7 & 1 & & 5 \\
Streptobacillusspp & 3 & 7 & 7 & 5 \\
Klepsiellaspp & 3 & 7 & & 5 \\
& & & & 5 \\
\hline
\end{tabular}

The pathogenic organism associated with herbal drinks marketed in Kaduna metropolis includes: Escherichia coli, Staphylococcus aureus, Pseudomonas aeruginosa, Bacillus moniformis, streptobacillu spp Klebsiella spp.

The limit of pathogenic organisms contamination given in European pharmacopoeia as reported by Okunola et al., (2007) are: total aerobic bacterial $\left(10^{5} \mathrm{cfu} / \mathrm{ml}\right) ;$ Klebsiella, and other Gram - negative organisms $\left(10^{3} \mathrm{cfu} / \mathrm{ml}\right)$; Escherichia coli and Staphylococcus aureus and other pathogenic organisms should be absent. The herbal products under study did not meet these specification as $100 \%$ of the samples had count above $10^{7} \mathrm{cfu} / \mathrm{ml}$. Of the herbal drink, $25 \%$ were contaminated with Escherichia coli, $17.5 \%$ had Bacillus moniformis, Staphylococcus aureus, Pseudomonas aeruginosa, Streptobacillus spp and Klepsiella spp had 7.5\% respectively.

The sspresence of large numbers of selected pathogenic organism in the analyzed herbal medicinal preparation in this study may be due to the methods of their preparations or contamination from equipment and materials used in preparing the herbal medicines. Other possible source of contamination are handling processes which could introduce the organisms when handling the raw material during processing,therefore, the process of harvesting, drying, storage, handling and the soil influences the microbial quality 
of raw material which in turn affects the entire quality of the herbal preparation (Abba et al., 2009).

Adeleye et al., (2004) reported that medicinal plant materials normally carry a large number of microbes originating from the soil.

Microorganisms of various kinds normally adhere to leaves, stems, flowers, seeds and roots. Additional contaminants may also be introduced during harvesting handling and production of various herbal remedies since no conscious efforts are made to decontaminate the herbs other than washing.

In this study the herbal medicinal preparations contained high level of bacterial beyond the Europeans pharmacopeia, which stated the limit. The presence of coliforms bacteria such Escherichia coli is the most reliable in direction of fecal contamination thus the test for their presence is an indication of the degree of fecal contamination (Jay, 2004).

These bacterial constitute the intestinal flora of humans and other animal and are therefore used as indicator organisms and as index of possible contamination by human pathogen which could be attributed to quality of water used in the preparation of the herbal medicine (Abba et al., 2009).

The significance of fecal bacterial is that if these specific bacteria are present then other harmful microorganisms may also be present such as Streptococcus faecalis .

Key:

R (Resistant); PEF (Pefloxacin);CN (Gentamyci);AU (augmentin);OFX (Ofloxacin)

AM (Amoxicillin); $\quad \mathrm{CH}$ (Chloranphenicol); $\mathrm{CPX}$ (ciprofloxacin); SP (Sparfloxacin)

SXT (septrin); S (Streptomycin); $\mathrm{R} \quad$ (Rocephin); E (Erythromycin); Z (Zinnacef).

The antibiotics sensitivity pattern revealed that Escherichia coli, Klebsiella spp, Pseudomona aeruginosa and Bacillus moniformis were more susceptible to Ciproflacin Gentamycin, Septrin, Pefloxacin and Sparfloxacin. Staphylococcus aureus was more sensitive to Ciprofloxacin, Septrin, Gentamycin, Amoxicillin and streptomycin also Streptobacillus spp are more sensitive to ciprofloxacin.

This study showed that the isolates were susceptible to the antibiotics tested. This is similar to the work of Shakler et al., (2004); Wylie and Nowiki, (2005) who revealed that organism such as Methicillin Resistant Staphylococcus aureus (MRSA), which are known to be resistant to multiple antibiotics tends to be susceptible to multiple antibiotics when they are of environmental origins and agrees with study by
Abba et al., (2009) who observed that environmental isolates are susceptible to most antibiotics.

\section{CONCLUSION}

Most of the herbal drinks marketed within Kaduna metropolis are contaminated with a variety of pathogenic microorganisms, such as Staphylococcus aureus, Escherichia coli, Pseudomonas aeruginosa, Bacillus moniliformis Streptobacillus spp and Klebsiella spp species.

The result of the antibiogram pattern of the bacterial isolate revealed that Escherichia coli, Baillus moniliformis, Pseudomonas aeruginosa, Klebsiella spp, Streptobacillus spp and Staphylococcous aureus were susceptible to Ciproflxacin, Gentamycin, Septrin, Pefloxcin, Sparfloxacin.

\section{ACKNOWLEDGMENTS}

Our thanks to Malama Jamilu for her Special contribution towards development of the template.

\section{REFERENCES}

[1] Bowman, M., Debray, S. K., and Peterson, L. L. 1993. Reasoning about naming systems. .

[2] Ding, W. and Marchionini, G. 1997 A Study on Video Browsing Strategies. Technical Report. University of Maryland at College Park.

[3] Fröhlich, B. and Plate, J. 2000. The cubic mouse: a new device for three-dimensional input. In Proceedings of the SIGCHI Conference on Human Factors in Computing Systems

[4] Tavel, P. 2007 Modeling and Simulation Design. AK Peters Ltd.

[5] Sannella, M. J. 1994 Constraint Satisfaction and Debugging for Interactive User Interfaces. Doctoral Thesis. UMI Order Number: UMI Order No. GAX9509398., University of Washington.

[6] Forman, G. 2003. An extensive empirical study of feature selection metrics for text classification. J. Mach. Learn. Res. 3 (Mar. 2003), 1289-1305.

[7] Brown, L. D., Hua, H., and Gao, C. 2003. A widget framework for augmented interaction in SCAPE.

[8] Y.T. Yu, M.F. Lau, "A comparison of MC/DC, MUMCUT and several other coverage criteria for logical decisions", Journal of Systems and Software, 2005, in press.

[9] Spector, A. Z. 1989. Achieving application requirements. In Distributed Systems, S. Mullender 
International Journal of Science and Engineering Applications

Volume 9 - Issue 10, 121 - 124, 2020, ISSN:- 2319 - 7560

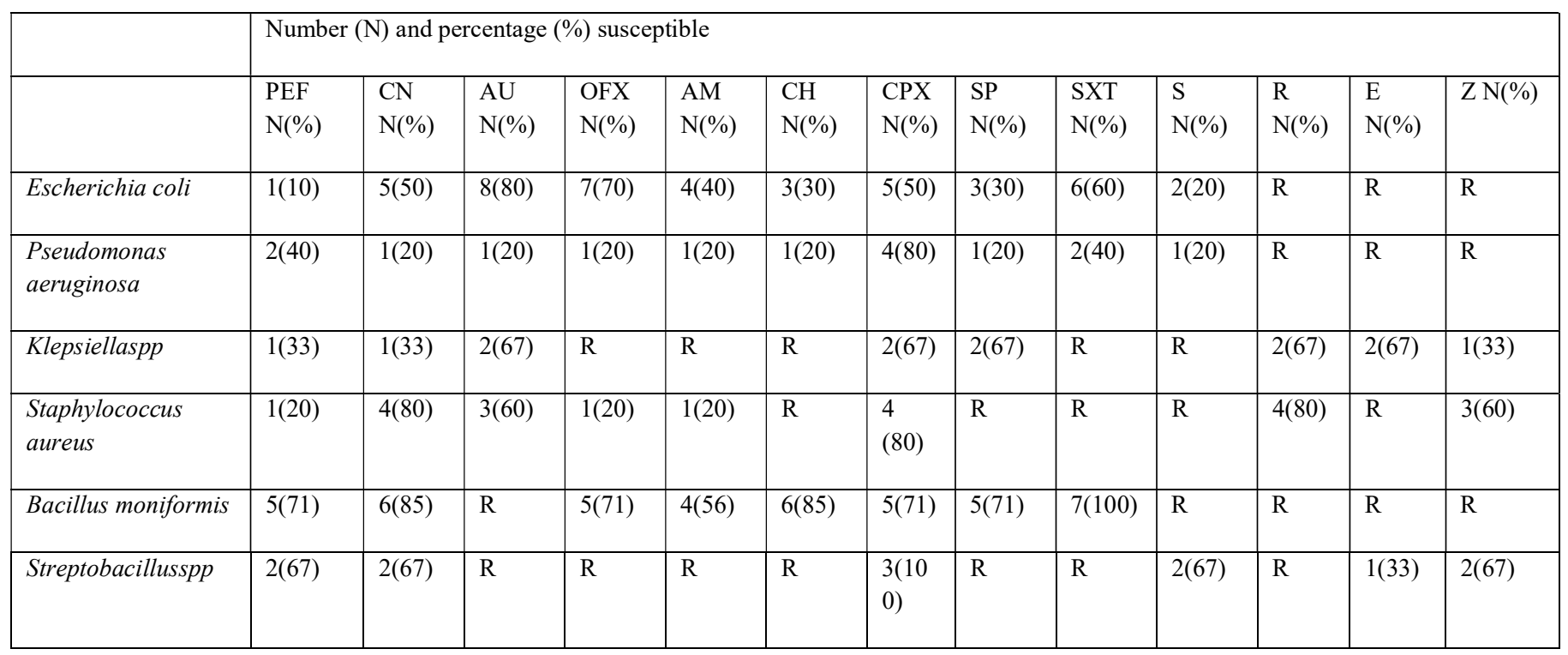

Table 3:Antibiogram pattern of Gram Positive and Gram Negative Isolates 